\title{
Reproductive System Findings Original Result
}

National Cancer Institute

\section{Source}

National Cancer Institute. Reproductive System Findings Original Result. NCI Thesaurus. Code C117644.

The outcome of the reproductive system findings assessment as originally received or collected. 